Borneo Journal of Sciences and Technology, Volume (1), Issue (1), Pages: 62-69

DOI: https://doi.org/10.35370/bjost.2019.1.1-12

e-ISSN: 2672-7439

(C) 2018, UCTS Publisher.

Submitted: 22 November 2018

Accepted: 25 November 2018

Published: 31 January 2019

\title{
Macroscopic and Microscopic Characteristics of 2- and 4-Year-Old Schizostachyum brachycladum
}

\author{
${ }^{1}$ Mohamad Saiful Sulaiman, ${ }^{1}$ Razak Wahab, ${ }^{2}$ Sitti Fatimah Mhd. Ramle, ${ }^{1}$ Nasihah Mokhtar and ${ }^{1}$ Ros \\ Syazmini Mohd Ghani \\ ${ }^{1}$ School of Engineering and Technology, University College of Technology Sarawak, 96000 Sibu, \\ Sarawak, Malaysia \\ ${ }^{2}$ Faculty of Bio Engineering and Technology, Universiti Malaysia Kelantan, 17600 Jeli, Kelantan, \\ Malaysia
}

\begin{abstract}
Anatomical of cell wall structure on Schizostachyum brachycladum examined. The harvested two-yearold and four-year-old bamboo culms segregated into the bottom, middle and top portions. The samples then undergo the Light Microscopy (LM), Scanning Electron Microscopy (SEM) and Transmission Electron Microscopy (TEM) to determine their structure such as a vascular bundle, parenchyma, and sclerenchyma. Results show the surface of bamboo was visualized by LM to decide on their structural figure. In this part, 2-year age indicated that higher numbers of vascular bundle and average of mean compared to the 4-year S. brachycladum. Followed by a specific study of cell wall structure using SEM with highlighted 4-year $S$. brachycladum had more complex of morphology structure compared to the 2-year-old. Later on, TEM illustrated to shows most depth anatomically structure of bamboo such as middle lamella, primary and secondary walls.
\end{abstract}

Keywords: Bamboo morphology, S. brachycladum, light microscopy, scanning electron microscopy, transmission electron microscopy, young bamboo, mature bamboo, bamboo anatomy.

\section{INTRODUCTION}

In the world's bamboo estimated at 31.5 million hectares and have over 75 genera and 1250 species across 21 countries [1]. In Peninsular Malaysia bamboo were covered at about 7\% from forest land, means estimated as 421,722 ha, of forest area with has about 59 bamboo species (25 cultivated species and 34 indigenous species) [2]. Bamboo is a vernacular term for members of the family Poaceae [3] and subfamily Bambusoideae with included both herbaceous bamboo or Olyreae tribe and woody bamboos or Bambuseae tribe [4]. Then automatically bamboo also included in grass family is Graminae, but the characteristics of bamboo are woody stems [2].

Traditionally, among the Malay folks, bamboo ( $S$. brachycladum) was utilized as a container in cooking Lemang, and it is as one of the famous rice cakes. The shoots were edible and had a good taste [5]. Bamboo is the second most crucial nontimber resource and ranked third after timber and rattan. Others, bamboo also is a fast-growing species and can mature within 3 to 4 years after cultivating [6] and [7]. The distinctive part of bamboo is a stem or called as culm, which has upper ground part that contains most of the woody material [23]. It was cheap material and occupy high mechanical properties among woody materials is currently being recognized as an option to wood [8]. Anatomically, the whole culms of bamboo comprise $40 \%$ fibers, which consisted of the vascular bundle and sclerenchyma. The remaining $60 \%$ of the total culm are considering parenchyma [9]. Studies in the bamboo culms anatomical structure undertaken by researchers so far have confined to species with thick culms wall. Rare previous studies have ever recorded on the bamboo with thin culms wall. Thin culms wall bamboo species such as $S$. brachycladum has been used for making flooring and panels by the rural communities as they simple to process and work with [5].

In this study, light microscope (LM) used for macrostructure viewing employed to the bamboo surface while scanning electron microscope (SEM) and transmission electron microscope (TEM) applied for indepth visualization microstructure of bamboo sample. The LM used for counting the significant number of the vascular bundle in the standardized surface area. The SEM provided for producing a scanned image at the spatial resolution and in low acceleration voltage area 
[10]. Also, available in wide range of magnifications, full three dimensions (transverse cross-section, tangential section, and radial section), excellent depth of field and straightforward specimen preparation [11]. On the other hand, TEM used to illustrated rare specimens (tissue section, molecules, etc.) through which electrons can pass generating a projection image [12].

\section{MATERIALS AND METHODS}

Two-year-old and four-year-old culms of $S$. brachycladum randomly selected and harvested from the forest areas in Jeli, Kelantan. Bamboo culms chose with diameters in the range from 5 to $6 \mathrm{~cm}$. Specimen were segregated into portions bottom, middle and top. The culms were cut approximately $30 \mathrm{~cm}$ from ground level. Samples were split to $10 \mathrm{~mm}$ x $10 \mathrm{~mm}$ cubes for the structure of cell wall prepared separately on Light Microscopy (LM) and Scanning Electron Microscopic (SEM). TEM sample was reduced to the small pieces (diameter $=0.5 \mathrm{~mm})$ and preserved into $3 \%$ concentration of glutaraldehyde.

\section{Anatomical structure under Light Microscopy (LM)}

The studies on parenchyma fiber, cell wall thickness, and vascular bundle were conducted according to methods described by [21] and [13]. Each part from $S$. brachycladum was cut into a cross section with $20 \mathrm{~mm} x$ $20 \mathrm{~mm} \times$ thickness (depending on species of bamboo thickness) as a sample dimension. Then, the samples were immediately scrutinized and photographed using a light microscopy Model Olympus SZX9, Olympus Optical, Japan.

\section{Anatomical structure analysis using Scanning Electron Microscopy (SEM)}

S. brachycladum visualized under Scanning electron microscopy (SEM) to characterize the morphology structure such as a vascular bundle, parenchyma fiber, vessel and structure of sclerenchyma [13]. The SEM micrographs were taken from the cross-section of samples into $5 \mathrm{~mm} \times 5 \mathrm{~mm}$ size of samples block. The samples with the dry condition were coated with gold by an ion sputter coater (Polaron SC515, Fisons Instruments, and United Kingdom). Then, the samples visualized by Scanning Electron Microscope LEO SUPRA 55 VP, Field Emission SEM, Carl-Zeiss, Oberkochen, Germany.

\section{Anatomical Structure on Transmission Electron Microscopy (TEM)}

The fresh of $S$. brachycladum with different ages taken from a cross-section of sample into $2.0 \times 0.5 \mathrm{~mm}$ size of the sample block. According to Spurr's resin method (1969), samples were fixed in karnosky's fixative with $3 \%$ glutaraldehyde and washed with $0.1 \mathrm{M}$ phosphate buffer. The specimen was postfixed in $1 \%$ Osmium tetraoxide and was left in for 2 hours. Next, the samples dehydrated with ethanol $50 \%, 75 \%, 95 \%, 100 \%$ of concentration and $100 \%$ of acetone then a mixture of acetone and Spurr's resin $(1: 1)$ used for the embed sample. Transverse section of thickness one $\mu \mathrm{m}$ was cut using Sorvall Ultra Microtome (MT500) with a diamond knife. The part stained with $2 \%$ uranyl acetate and lead citrate. Transverse section examined with a LEO in column EFTEM with OMEGA spectrometer, Zeiss, Libra 120.

\section{RESULTS AND DISCUSSION}

\section{Structural of $S$. brachycladum under light microscopy (LM) analysis}

The anatomical structure cell of parenchyma and vascular bundle on $S$. brachycladum was characterized in different ages (2-year and 4-year) and portions (top, middle, and bottom) as showed as in Figure 1.S. brachycladum culm consists of parenchyma, vascular bundle, sclerenchyma, and vessel. Moreover, the area of each image (a; b; c; d; e and f) standardized to uniformed scale which is under 50 magnification. From the observation, the bottom portion from 2-year and 4year had less compact on some vascular bundles compared than another image (b, c, e and f) while on the bottom portion of 2-year and 4-year also were visualized more clearly and utterly vascular bundle structure. Based on the previous study, believed that the vascular bundle is smaller and more numerous at the peripheral zone of bamboo culm while in the inner parts the vascular bundle becomes larger and fewer as shown in Figure 1 [14]. Proven by [22] study, the vascular bundle is oval and varies in sizes depending on the location or position as well as species of bamboo.

According to Table 1 and Table 2, the statistical analysis of homogeneous and ANOVA was indicated that the 4-year $S$. brachycladum had a significant difference with a mean of the vascular bundle based on the surface area counted which is 8.00 , 8.00 and 14.33 at the bottom, middle and top, respectively. 2-year $S$. brachycladum had not significantly different with the average mean value shows 9.00, 10.00 and 16.33 for the bottom, middle, and top, respectively. According to [15] the most content in culm tissue is parenchyma with about $50 \%$, 
followed by fiber for $40 \%$ and the rest vascular bundle (vessel and sieve tubes with companion cells) at about $10 \%$ as shown in Figure 1, but with some variation it purpose, the different of sclerenchyma and parenchyma were also can classify based on their contrasted by the darker coloured is sclerenchymatous tissue and lightly stained is the parenchymatous ground tissue. In another hand, the anatomical structure of the bamboo culm supported for understanding the basic physical characterization of bamboo and is responsible for fiber dimension to vary cross and along the bamboo culm [17].

Table 1: Statistical analysis of homogenous subsets due to the age for light microscopy (LM) on $S$.

$$
\text { brachycladum }
$$

\begin{tabular}{lll}
\hline Parameter & 4-year-old & 2-year-old \\
\hline Bottom & $8.00^{\mathrm{a}} \pm 1.00$ & $9.00^{\mathrm{a}} \pm 2.00$
\end{tabular}

happens according to species. So, vascular bundle appearance is important to observe the differences between and within species [16]. For identification Middle $\quad 8.00^{\mathrm{a}} \pm 1.00 \quad 10.00^{\mathrm{ab}} \pm 4.36$

Top $14.33^{\mathrm{b}} \pm 2.31 \quad 16.33^{\mathrm{b}} \pm 3.79$

Table 2: ANOVA for light microscopy (LM) on $S$. brachycladum due to the age

\begin{tabular}{lllllllll}
\hline $\begin{array}{l}\text { Para } \\
\text { meter }\end{array}$ & $\mathrm{SS}^{\mathrm{a}}$ & $\mathrm{SS}^{\mathrm{b}}$ & $\begin{array}{l}\mathrm{d} \\
\mathrm{f}^{\mathrm{a}}\end{array}$ & $\begin{array}{l}\mathrm{d} \\
\mathrm{f}^{\mathrm{b}}\end{array}$ & $\begin{array}{l}\mathrm{MS} \\
\mathrm{a}\end{array}$ & $\begin{array}{l}\mathrm{MS} \\
\mathrm{b}\end{array}$ & $\mathrm{F}$ & $\begin{array}{l}\mathrm{Sig} \\
.\end{array}$ \\
\hline $\begin{array}{l}\text { 4- } \\
\text { year- } \\
\text { old }\end{array}$ & 66. & 14. & 2 & 6 & 34. & 2.4 & 14. & 0.0 \\
\hline $\begin{array}{l}\text { 2- } \\
\text { year- } \\
\text { old }\end{array}$ & 94. & 749 & & & 778 & 44 & 227 & 05 \\
\hline
\end{tabular}



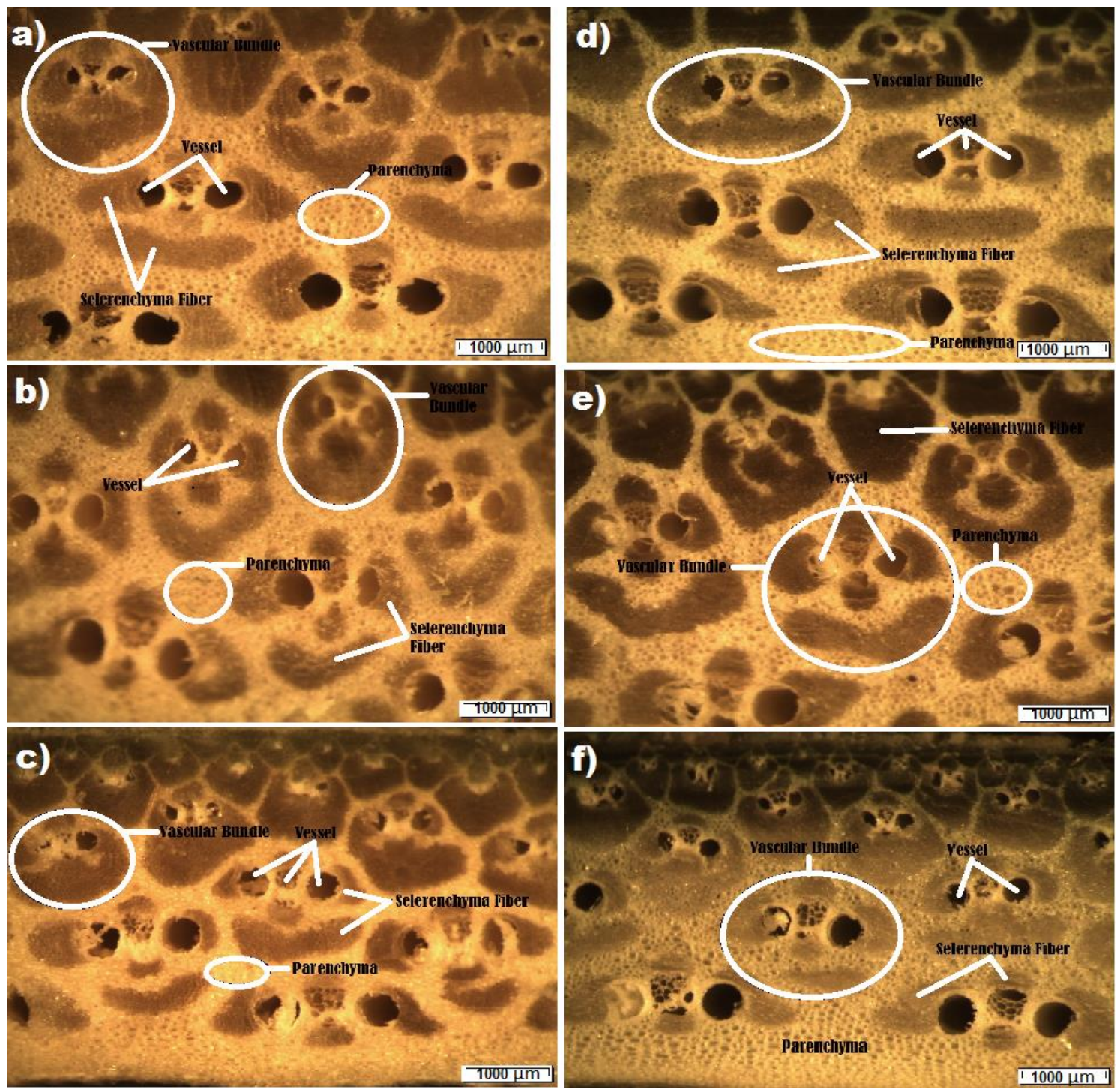

Figure 1: Light microscopy S. brachycladum which is (a), (b) and (c) are the bottom, middle and top for 4-year age, respectively while (d), (e), and (f) are the bottom, middle and top for a 2-year age, respectively.

Structural of $S$. brachycladum under scanning electron microscopy (SEM) analysis

The Scanning Electron Microscopy (SEM) viewed more clearly cell wall structure of the parenchyma, sclerenchyma, vascular bundle and vessel compare to the light microscopy (LM). But, SEM was still limited to observe in depth cell wall fiber inside individually. Figure 2, (a) and (b) represented as 4year S. brachycladum while (c) and (d) represented as 2-year $S$. brachycladum. There were illustrated in both image and consisted not too much of difference between others. In-depth observation on Figure 2 (a) and (b) show parenchyma fiber had a thicker wall and stronger texture compared to the Figure 2 (c) and (d) with believing that had high capabilities to support the massive load. Based on the previous study, the number of layers is mostly restricted from two to four in parenchyma wall whereby with the herringbone pattern of fibrillar arrangement [18] and [15]. Moreover, as reported by [20] on bamboo based the parenchymatous ground cell was outlined by a thin cell wall and large cell lumen with diameter average to $15 \mathrm{~mm}$ while thick cell wall and small cell lumen characterized on sclerenchyma fiber with diameter around $5 \mathrm{~mm}$ and. 

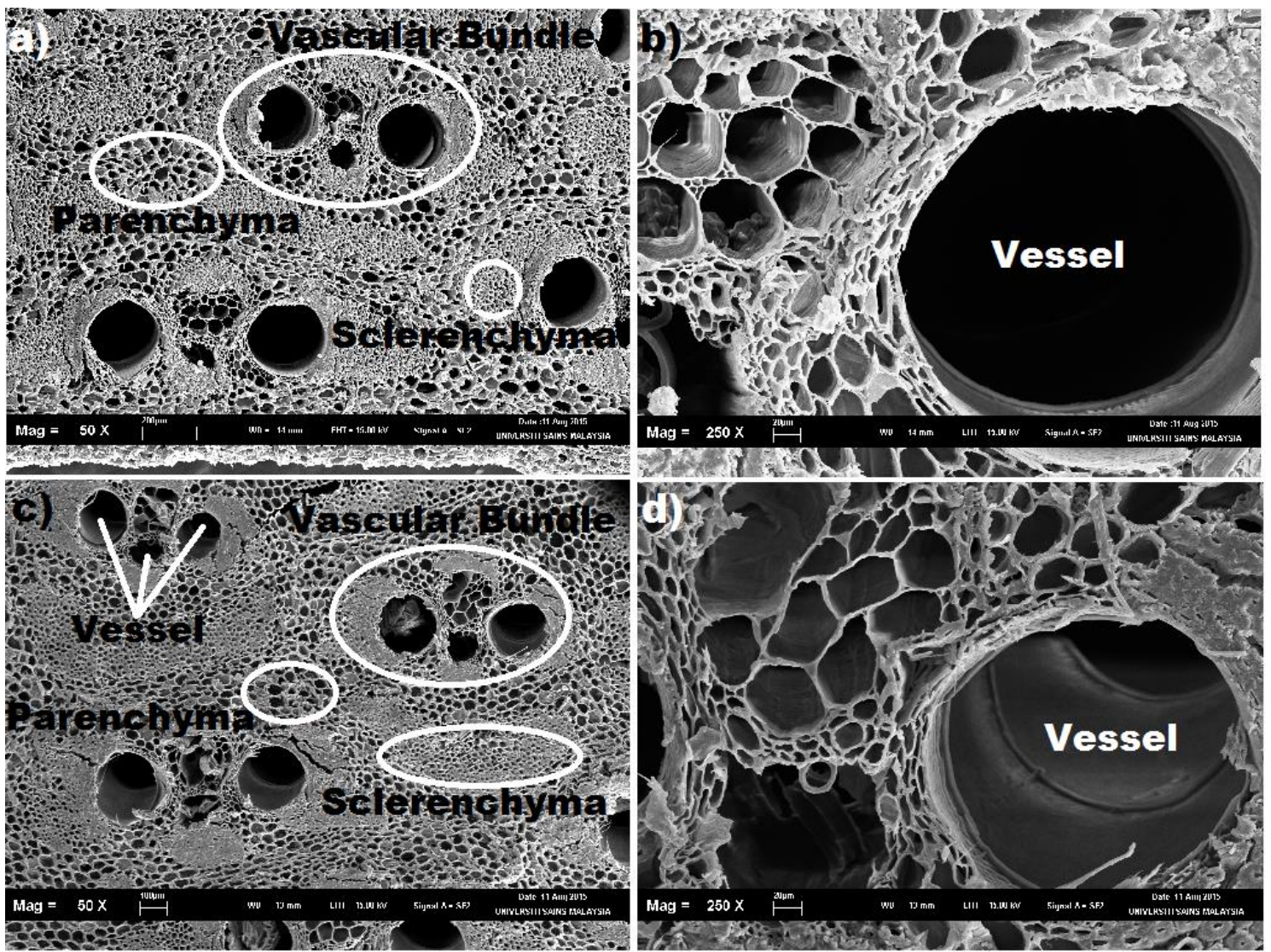

Figure 2: Scanning Electron Microscopy (SEM) of S. brachycladum which is (a) and (b) consist on 50x and 250x of magnification for 4-year-old, respectively while (c) and (d) consist on 50x and 250x of magnification for a 2-year-old, respectively.

Structural of S. brachycladum under transmission electron microscopy (TEM) analysis

Figure 3 (a), (b) represented as 4-year $S$. brachycladum and Figure 3 (c), (d) indicated of 2year $S$. brachycladum. Figures illustrated that the cell wall structure of parenchyma cell with clearly using the Transmission Electron Microscopy (TEM) compared than to SEM and LM. The figure also shows that the primary wall $(\mathrm{P})$, secondary wall $(\mathrm{S})$ and middle lamella (ML) appeared as a thin layer. According to the study of the anatomical structure by [18], there are two types of microfibril orientation in bamboo which are the broader ones with fibrillar angle almost parallel to an axis and the narrow lamellae showing the fibrillar angle of $80-90^{\circ}$ to the axis. Although the fibers in bamboo demonstrated that polylamellate nature with eight lamellae (S1-1, S2-t, S3-1, S4-t, S5-1, S6-t, S7-1, and S8-t) compare to the wood with only three lamellae (S1, S2, and S3). Next, the thick fibril layer which is parallel to the axis is transcendent compared to the narrow lamellae. The thickness and structure of cell wall were affected the strength properties and density.

Figure 3 highlighted S1, and S2 layers consist of the lignin distributed homogeneously. However, the lignin level increased in the middle lamella (ML) and cell corner. Reported by [19] seen from the SEM and TEM images that possibly be the lignin-rich at corner middle lamella and it was the most durable in physically. Also, frequently show hemicellulose consisted more content on the S1 layer and cellulose more consists in the $\mathrm{S} 2$ layer. Based on [15] study, the walls of vessels on bamboo are characterized by a middle lamella and a primary wall together with a well-developed gap of the secondary wall into S1 and S2. Figure 3 highlighted 2-year $S$. brachycladum assume content more lignin and cellulose because the part had more numerous of cell corner and thicker middle lamella and S2 layer compared than 4-year S. brachycladum. 


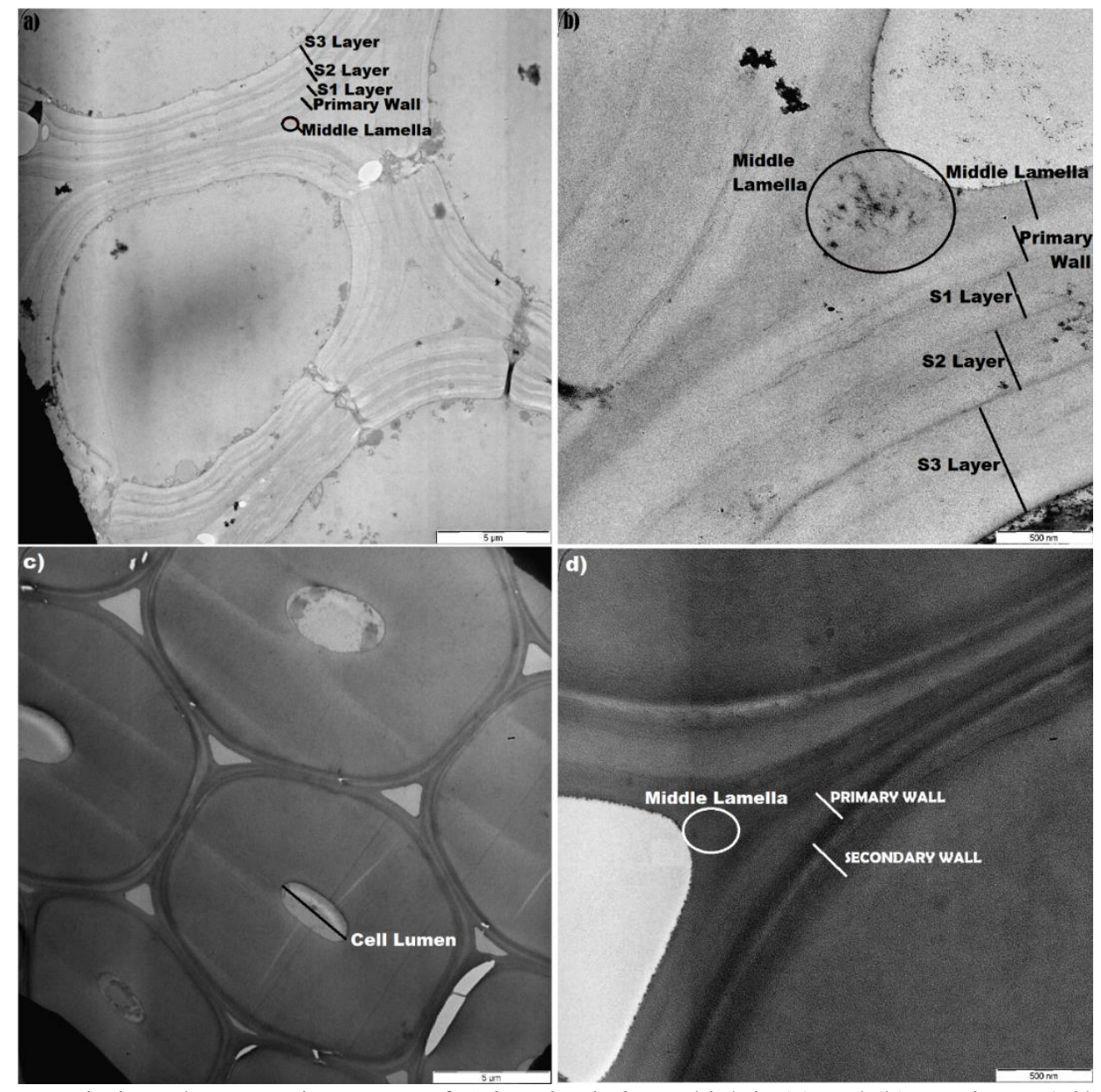

Figure 3: Transmission Electron Microscopy of S. brachycladum which is (a) and (b) consist on $1.3 \mathrm{k}$ and 10k of magnification for 4-year-old, respectively while (c) and (d) consist on 1.3k and 10k of magnification for a 2-yearold, respectively.

\section{CONCLUSION}

Study on the micrograph of the vascular bundle, parenchyma, sclerenchyma, and vessel of two-year-old and four-year-old S. brachycladum highlighted LM surface area of vascular bundle and parenchyma cell structure compared than with SEM and TEM. At the same magnification on surface area, LM analyses show that the 2-year $S$. brachycladum had a slightly higher percentage of vascular bundle compared to the 4-year $S$. brachycladum SEM analyses highlighted not drastically different between 2-year and 4-year or on their magnification showed. TEM indicated 4-year-old consisted of more clear structure of layer (ML, Primary layer and Secondary layer) compared to the 2-year-old species. The overall 4-year $S$. brachycladum designated that most clear cell wall structure which is a vascular bundle, parenchyma, sclerenchyma fiber, and vessel compared to the 2-year S. brachycladum. An in-depth study on TEM has indicated that 4-year age had most clear of morphology structure of $S$. brachycladum. 4- year also shows TEM analyses had some layer (primary layer, secondary layer, and middle lamella) that believed contained lignocellulosic compounds such as cellulose, hemicellulose, lignin, and other substances.

\section{ACKNOWLEDGMENT}

This work supported by the Fundamental Research Grant Study (R/FRGS/A08.00/00801A/001/2013/00110). We would like to express our gratitude Universiti Malaysia Kelantan (UMK) for the cooperation regarding laboratory use to complete the sample preparation. Grateful also to Universiti Sains Malaysia (USM) for the collaboration on apparatus and machinery used to anatomical structure visualized with successfully. Nevertheless, thanks to University College of Technology Sarawak (UCTS) for facilities provided. 


\section{REFERENCES}

[1] Shanmughavel, P., Peddappaiah, R. S., \& Muthukumar, T. (2001). Biomass production in an age series of Bambusa bambos plantations, 20, 113-117.

[2] Bahari, S. A., \& Krause, A. (2016). Utilizing Malaysian bamboo for use in thermoplastic composites. Journal of Cleaner Production, 110, 16-24.

[3] Chaowana, P. (2013). Bamboo: An Alternative Raw Material for Wood and Wood-Based Composites. Journal of Materials Science Research, 2(2).

[4] Yeasmin, L., Ali, M. N., Gantait, S., \& Chakraborty, S. (2014). Bamboo: an overview on its genetic diversity and characterization. 3 Biotech, 5(1), 1-11.

[5] Anokye, R., Bakar, E. S., Abare, A. Y., Kalong, R. M., \& Muhammad, A. (2014). The Difference in Density along the Bamboo Culms of Gigantochloa Scortichinii and Bambusa Vulgaris, 4(10), 3-8.

[6] Sulaiman, M.S., Wahab, R., Mhd Ramle, S.F., Ghani, R.S.M. \& Mokhtar, N. (2018b). Relationship between Chemical Compositions and Anatomical Structure on the Maturity of 4Year-Old Culms Schizostachyum brachycladum Kurz. International Journal of Current Research, Vol. 10, Issue, 05, pp.69776-69780.

[7] Wahab, R., Mustafa, M.T., Norashikin F., Ghani, R.S.M., Sulaiman, M.S., Mokhtar, N. \& Sim, T.K. (2018a). The Effects of Anatomy and Physical Properties on the Strength of Cultivated FourYear-Old Bambusa vulgaris. International Journal of Current Research. Vol. 10, Issue, 02, pp.6543965448.

[8] Wahab, R., Mokhtar, N., Ghani, R.S.M., Sulaiman, M.S. \& Samsi, H.W. (2018b). Changes in Strength Characteristics and Durability on 4Year-Old Tropical Bamboo Gigantochloa Scortechinii through Heat Treatment. Asian Journal of Science and Technology. Vol. 09, Issue, 05, pp.8227-8233.

[9] Wahab, R., Mohammed A. S., Aminuddin M., Hashim W. S., Shafiqur R., Rasat M. S. M. and Izyan K., 2015. Evaluation on Strength of Chemically Treated 2 and 4 year-old Bamboo Bambusa vulgaris through Pressurized Treatment. Research Journal of Pharmaceutical, Biological and Chemical Sciences - February. ISSN: 09758585 .

[10] Wahab, R., Mahmud, S., Tamizi, M. \& Awang, M.Y. (2006). Durability performance of Gigantochloa scortechinii through laboratory fungal decay tests. Research Journal of
Microbiology 1(2): 198-202, 2006. ISSN: 18164935, Academic Journals Inc. USA.

[11] Wahab, R., Murphy, R.J. and Samsi, H.W. (2002). SEM observations on decay of Gigantochloa scortechinii bamboo exposed in tropical soil. Journal of Tropical Forest Products, (JTFP) 8(2): 12(2002). Pp 168-178.

[12] Wahab, R. (1998). Effect of selected preservatives on the durability of Gigantochloa scortechinii. A $\mathrm{PhD}$ thesis, University of London

[13] Wahab, R., Tamizi, M., Othman, S., Aminuddin, M., Affendy, H. \& Izyan, K. (2010). Anatomy and physical properties of cultivated 2 and 4 year-old Bambusa vulgaris. ISSN: 0126-6039. Journal of Science Malaysiana 39 (4)(2010): 53-61

[14] Sulaiman, M.S., Ramle, S.F.M., Geng, B.J., Hashim, R., Sulaiman, O., Ibrahim, N.I., Zaudin, N.A.C. (2016). Bambusa vulgaris: Chemical Composition and Cell Wall Structure. European International Journal of Science and Technology, 5(9), 27-39.

[15] Liese, W. (1985). "Anatomy and properties of bamboo." Proceedings of the International Bamboo Workshop.

[16] Liese, W., (1992). The structure of bamboo in relation to its properties and utilization. In $\mathrm{Zhu}$, S., Li, W., Zhang, X. Wang, Z. ed., Bamboo and its use. Proceedings of the International Symposium on Industrial Use of Bamboo, Beijing, China, 7-11 December 1992. International Tropical Timber Organization: Chinese Academy of Forestry, Beijing, China. Pp 96-100.

[17] Espiloy, Z.B. (1985). Physico-Mechanical Properties and Anatomical Relationships of Some Philippine Bamboos. Forest Products Research and Development Institute, NSTA, College, Laguna 3720, Philippines.

[18] Parameswaran, N., \& Liese, W. (1980). Ultra structural aspects of bamboo cells. Cell. Chem. Technology 14: 587609.

[19] Cha, M.Y., Lee, K.H., Kim, Y.S. (2014). Micromorphological and chemical aspects of archaeological bamboos under long-term waterlogged condition. Int Bio deterior Biodegr; 86(part B):115-21.

[20] Li, M.-Y., Fang, B.-S., Zhao, Y., Tong, T., Hou, X.-H., \& Tong, H. (2014). Investigation into the deterioration process of archaeological bamboo strips of China from four different periods by chemical and anatomical analysis. Polymer Degradation and Stability, 109, 71-78.

[21] Sulaiman, M.S., (2018a). Characterization and Anatomical Properties of $S$. brachycladum Kurz and B. vulgaris Schrad Grown in Kelantan, 
Malaysia. A MSc. Thesis, Universiti Malaysia Kelantan. (Unpublished).

[22] Wahab, R., Samsi, H.W., Mohamed, A. \& Janshah, M. (2005). Energy dispersive x-ray analysis on preservatives treated tropical bamboo species. Journal of Biological Science, 5 (6): 837841: 2005, ISSN 1727-3048. Asian Network for Scientific Information.

[23] Sulaiman M.S., Ramle S.F.M., Hashim R., Sulaiman O., Amini M.H.M. and Geng B.J. (2018c). The Classical Mechanics Engineered of Bambusa vulgaris and Schizostachyum brachycladum. Journal of Tropical Resources and Sustainable Science, 6 (2018): 57-61. 